\title{
UJI AKTIVITAS ANTIOKSIDAN EKSTRAK METANOL BUNGA BROKOLI (Brassica oleracea L. var. Italica) DENGAN METODE DPPH (2,2 diphenyl-1-picrylhydrazyl) dan METODE ABTS (2,2 azinobis (3-etilbenzotiazolin)-6-asam sulfonat)
}

\author{
Fitriyanti Jumaetri Sami ${ }^{1}$, Sitti Rahimah ${ }^{1}$ \\ 'Sekolah Tinggi Ilmu Farmasi Makassar \\ email : fitriyantijumaetri_sami@yahoo.com
}

\begin{abstract}
Telah dilakukan penelitian uji aktivitas antioksidan ekstrak metanol bunga brokoli (Brassica oleracea L. var. Italica) dengan menggunakan metode DPPH (2,2-diphenyl-1-picrylhydrazyl) dan metode ABTS (2,2-Azinobis (3etilbenzotiazolin)-6-asam sulfonat). Bunga brokoli diekstraksi secara maserasi dengan menggunakan pelarut metanol. Ekstrak bunga brokoli (Brassica oleracea L. var. Italica) dibuat dalam berbagai konsentrasi dan diuji aktivitas antioksidannya. Pada metode DPPH diperoleh nilai IC $_{50}$ sebesar 123,698 ppm dan IC $_{50}$ vitamin $\mathrm{C}_{\text {murni }}$ sebesar 3 ppm sedangkan pada metode ABTS diperoleh nilai $\mathrm{IC}_{50}$ sebesar 32,1292 ppm dan nilai $\mathrm{IC}_{50}$ vitamin $\mathrm{C}$ murni sebesar 6 ppm.
\end{abstract}

Kata Kunci : Antioksidan, Bunga Brokoli (Brassica oleracea L. var. Italica), metode DPPH dan Metode ABTS

\section{PENDAHULUAN}

\section{A. Latar Belakang}

Radikal bebas adalah suatu senyawa atau molekul yang mengandung satu atau lebih elektron yang tidak berpasangan pada orbital luarnya. Adanya elektron yang tidak berpasangan menyebabkan senyawa tersebut sangat reaktif mencari pasangan dengan cara menyerang dan mengikat elektron molekul yang berada di sekitarnya seperti lipid, protein maupun DNA (Winarsi, 2007). Antioksidan adalah zat yang dapat menangkal atau mencegah reaksi oksidasi dari radikal bebas. Oksidasi merupakan suatu reaksi kimia yang mentransfer elektron dari satu zat ke oksidator. Reaksi oksidasi dapat menghasilkan radikal bebas dan memicu reaksi berantai, menyebabkan kerusakan sel dalam tubuh (Miksusanti dkk, 2012). Sayuran jenis Cruciferae (family Brassicaceae) merupakan sumber antioksidan yang berlimpah. Salah satu jenis dari family tersebut adalah tanaman brokoli (Brassica oleracea L. var. Italica). Selain mengkonsumsi suplemen, cara untuk memenuhi kebutuhan antioksidan yaitu dengan mengkonsumsi sayuran. Brokoli merupakan salah satu jenis sayuran yang memiliki kandungan karotenoid, flavonoid, vitamin A, C, E, tiamin, riboflavin, betakaroten, lutein dan glutation yang bersifat antioksidan (Jusuf dan Nelva, 2012). Yuliani, (2012), mendapatkan hasil bahwa lutein yang ada pada tanaman brokoli mempunyai antioksidan paling tinggi dibandingkan dengan kubis, kembang kol dan kecambah. Pada penelitian ini dilakukan pengujian antioksidan ekstrak metanol bunga brokoli (Brassica oleracea L. var. Italica). Adanya kandungan zat aktif tersebut maka diperlukan suatu kajian mengenai aktivitas antioksidan dengan metode DPPH dan ABTS.

Tujuan penelitian ini adalah untuk mendapatkan aktivitas antioksidan ekstrak metanol bunga brokoli (Brassica oleracea L. var. Italica) terhadap radikal bebas DPPH dan ABTS serta metode yang tepat untuk menentukan aktivitas antioksidan. Penelitian ini diharapkan dapat memberikan informasi antioksidan bunga brokoli kepada masyarakat dan para peneliti selanjutnya.

\section{METODE PENELITIAN}

\section{A. Alat dan Bahan}

Alat yang digunakan yaitu bejana maserasi, cawan porselin, gelas ukur, labu terukur $5 \mathrm{ml}, 10 \mathrm{ml}$, $50 \mathrm{ml}, 100 \mathrm{ml}, 250 \mathrm{ml}$, beaker gelas, erlenmeyer, vial, mikropipet, pipet tetes, neraca analitik, tissue, aluminium foil, sendok tanduk, batang pengaduk dan spektrofotometer UV-VIS (Agiment Technologies G1030 AX-DE 017 43058).

Bahan-bahan yang digunakan yaitu aquadest, metanol absolut, etanol absolut, DPPH, ABTS, vitamin C murni, ekstrak bunga brokoli (Brassica oleracea L. var. Italica).

\section{B. Prosedur Penelitian \\ 1. Pengolahan Sampel}

Bunga brokoli (Brassica oleracea L. var. Italica) diambil kemudian dicuci bersih dengan air mengalir, ditiriskan lalu diiris halus.

\section{Pembuatan Ekstrak Metanol}

Sampel ditimbang sebanyak 300 gram kemudian dimasukkan dalam wadah dan diekstraksi secara maserasi selama 1 x 24 jam dengan 
menggunakan cairan penyari metanol sambil sesekali diaduk, kemudian disaring. Ampas hasil ekstraksi kemudian diremaserasi lagi. Filtrat yang diperoleh dikumpulkan dan dipekatkan dengan ratory evaporator sampai diperoleh ekstrak kental.

\section{Uji Aktivitas Antioksidan \\ 1. Pembuatan Larutan DPPH 0,4 mM}

DPPH ditimbang sebanyak 0,01577 $\mathrm{g}$ dan dilarutkan dengan metanol absolut hingga $100 \mathrm{ml}$ dalam labu ukur.

\section{Pembuatan Larutan Stok Ekstrak Bunga Brokoli}

Larutan stok 1000 ppm disiapkan dengan cara ditimbang $50 \mathrm{mg}$ ekstrak kental bunga brokoli dan dilarutkan dengan metanol absolut sambil dihomogenkan, volume akhir dicukupkan metanol absolut sampai $50 \mathrm{ml}$ dalam labu ukur.

\section{Pembuatan Larutan Stok Vitamin C Murni}

Larutan stok 1000 ppm disiapkan dengan cara menimbang $50 \mathrm{mg}$ vitamin $\mathrm{C}$ murni dan dilarutkan dengan metanol absolut, volume akhir dicukupkan hingga $50 \mathrm{ml}$ labu ukur.

4. Pembuatan larutan stok ABTS

a. Larutan a : Ditimbang 7,1015 mg ABTS, dilarutkan dalam $5 \mathrm{ml}$ aquadest. Diinkubasi selama 12 jam

b. Larutan b : Ditimbang 3,500 mg $\mathrm{K}_{2} \mathrm{~S}_{2} \mathrm{O}_{8}$, dilarutkan dalam $5 \mathrm{ml}$ aquadest. Diinkubasi selama 12 jam

c. Larutan a dan b dicampur dalam ruang gelap dan cukupkan volumenya dengan etanol absolut sampai $25 \mathrm{ml}$.

\section{Pengukuran Aktivitas Antioksidan Dengan} Metode DPPH

\section{a. Pengukuran serapan Larutan Blanko DPPH}

Larutan DPPH 0,4 mM dipipet sebanyak 1 $\mathrm{ml}$ dan dicukupkan volumenya sampai $5 \mathrm{ml}$ dengan metanol absolut dalam labu terukur. Larutan ini kemudian dihomogenkan dan dibiarkan selama 30 menit, selanjutnya serapan diukur dengan spektrofotometri UV-Vis pada panjang gelombang $515 \mathrm{~nm}$.

\section{b. Pengukuran Aktivitas Pengikatan Radikal bebas DPPH dengan Sampel}

Pengujian dilakukan dengan cara memipet masing-masing $400 \mu 1,500 \mu 1,600 \mu 1,700 \mu l$ dan $800 \mu \mathrm{l}$ dari larutan stok sampel bunga brokoli 1000 ppm, campuran ditambah $1 \mathrm{ml}$ DPPH $0,4 \mathrm{mM}$ lalu dicukupkan volumenya sampai $5 \mathrm{ml}$ dengan metanol absolut sehingga diperoleh larutan dengan konsentrasi 80 ppm, 100 ppm, 120 ppm, 140 ppm dan 160 ppm. Selanjutnya dihomogenkan dan dibiarkan selama 30 menit, lalu diukur serapan dengan spektrofotometri UV-Vis pada panjang gelombang $515 \mathrm{~nm}$.

Besarnya persentase pengikatan radikal bebas dihitung dengan rumus :

$\%$ pengikat radikal $=\frac{(\text { Abs Blanko-Abs Sampel })}{\text { Absorbansi Blanko }} \times 100 \%$

Nilai $\mathrm{IC}_{50}(50 \%$ Inhibitory Concentration) ditentukan dengan analisis probit dari data log konsentrasi dengan probit persentase pengikatan radikal bebas.

\section{Pengukuran Aktivitas Pengikatan Radikal bebas DPPH dengan vitamin C murni}

Pengujian dilakukan dengan memipet masing-masing $10 \mu \mathrm{l}, 12.5 \mu \mathrm{l}, 15 \mu \mathrm{l}, 17.5 \mu \mathrm{l}$ dan 20 $\mu \mathrm{l}$ dari larutan stok vitamin $\mathrm{C}$ murni $1000 \mathrm{ppm}$, campuran ditambah $1 \mathrm{ml}$ DPPH $0,4 \mathrm{mM}$ lalu dicukupkan volumenya sampai $5 \mathrm{ml}$ dengan metanol absolut sehingga diperoleh larutan dengan konsentrasi 2 ppm, 2.5 ppm, 3 ppm, 3.5 ppm dan 4 ppm, kemudian dihomogenkan dan dibiarkan selam 30 menit. Selanjutnya serapan diukur dengan spektrofotometri UV-Vis pada panjang gelombang $515 \mathrm{~nm}$.

\section{Pengukuran Aktivitas Antioksidan Dengan Metode ABTS}

a. Pengukuran Serapan Larutan Blanko ABTS Larutan ABTS dipipet sebanyak $1 \mathrm{ml}$ dan dicukupkan volumenya sampai $5 \mathrm{ml}$ dengan etanol absolut dalam labu terukur. Larutan ini kemudian diukur dengan spektrofotometri UV-Vis pada panjang gelombang $750 \mathrm{~nm}$.

b. Pengukuran Aktivitas Pengikatan Radikal bebas ABTS dengan Sampel

Larutan stok sampel ekstrak bunga brokoli $1000 \mathrm{ppm}$ dipipet masing-masing $50 \mu 1,100$ $\mu \mathrm{l}, 150 \mu \mathrm{l}, 200 \mu \mathrm{l}$ dan $250 \mu \mathrm{l}$, campuran ditambah 1 ml larutan ABTS lalu dicukupkan volumenya sampai $5 \mathrm{ml}$ dengan etanol absolut sehingga diperoleh larutan dengan konsentrasi 10 ppm, 20 ppm, 30 ppm, 40 ppm dan 50 ppm. Selanjutnya dihomogenkan lalu diukur serapan dengan spektrofotometri UV-Vis pada panjang gelombang $750 \mathrm{~nm}$.

Besarnya daya antioksidan dihitung dengan rumus :

Daya antioksidan $=\frac{(\text { Abs Blanko-Abs Sampel })}{\text { Absorbansi Blanko }} \times 100 \%$

\section{c. Pengukuran Aktivitas Pengikatan Radikal bebas ABTS dengan vitamin c murni}

Pengujian dilakukan dengan memipet masing-masing $15 \mu \mathrm{l}, 20 \mu \mathrm{l}, 25 \mu \mathrm{l}, 30 \mu \mathrm{l}$ dan $35 \mu \mathrm{l}$ dari larutan stok vitamin C murni 1000 ppm, campuran ditambah $1 \mathrm{ml}$ larutan ABTS lalu dicukupkan volumenya sampai $5 \mathrm{ml}$ dengan etanol 
absolut sehingga diperoleh larutan dengan konsentrasi 3 ppm, 4 ppm, 5 ppm, 6 ppm dan 7 ppm. Selanjutnya dihomogenkan lalu serapan diukur dengan spektrofotometri UV-Vis pada panjang gelombang $750 \mathrm{~nm}$.

\section{Hasil dan Pembahasan}

Uji aktivitas antioksidan dengan metode DPPH berdasarkan hilangnya warna ungu akibat tereduksinya DPPH oleh antioksidan. Intensitas warna ungu yang hilang diukur dengan spektrofotometer UV-VIS pada panjang gelombang $515 \mathrm{~nm}$. Sedangkan uji antioksidan dengan metode ABTS berdasarkan hilangnya warna biru akibat tereduksinya ABTS oleh antioksidan. Intensitas warna biru ini diukur pada panjang gelombang 750 nm.

Tiap konsentrasi yang diperoleh kemudian diukur pada spektrofotometer UV-Vis dengan vitamin C murni sebagai pembanding (kontrol positif). Aktivitas antiradikal bebas ditunjukkan dengan nilai $\mathrm{IC}_{50}$. Nilai $\mathrm{IC}_{50}$ merupakan nilai konsentrasi antioksidan untuk meredam 50\% aktivitas radikal bebas.

Pada pengujian aktivitas antioksidan dengan metode DPPH menunjukkan bahwa ekstrak metanol bunga brokoli (Brassica oleracea L. var. Italica) mempunyai nilai $\mathrm{IC}_{50}$ sebesar 123,698 ppm dan vitamin $\mathrm{C}$ murni sebagai pembanding mempunyai $\mathrm{IC}_{50}$ sebesar 3 ppm. Semakin kecil nilai $\mathrm{IC}_{50}$ berarti semakin kuat daya antioksidannya. Nilai $\mathrm{IC}_{50}$ ekstrak metanol bunga brokoli lebih besar dari nilai $\mathrm{IC}_{50}$ vitamin $\mathrm{C}$ murni. Hal ini menunjukkan bahwa daya antioksidan ekstrak metanol bunga brokoli lebih lemah dibandingkan antioksidan vitamin $\mathrm{C}$ murni.

Pada pengujian aktivitas antioksidan menggunakan metode ABTS menunjukkan ekstrak metanol bunga brokoli (Brassica oleracea L. var. Italica) mempunyai nilai $\mathrm{IC}_{50}$ sebesar $32,1292 \mathrm{ppm}$ dan vitamin $\mathrm{C}$ murni sebagai pembanding

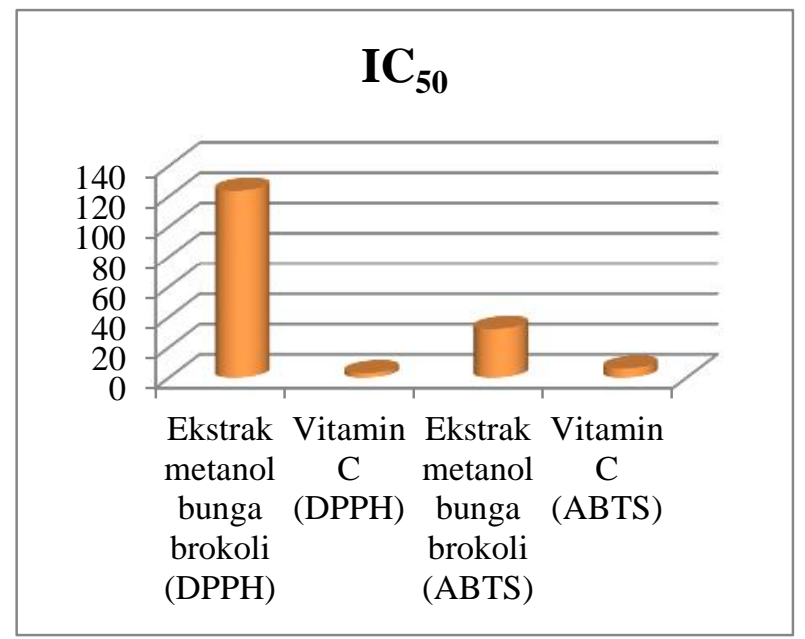

mempunyai nilai $\mathrm{IC}_{50}$ sebesar $6 \mathrm{ppm}$. Berdasarkan nilai $\mathrm{IC}_{50}$ menunjukkan aktivitas antioksidan ekstrak metanol bunga brokoli lebih lemah dibandingkan vitamin $\mathrm{C}$ murni.

Grafik di atas menunjukkan nilai $\mathrm{IC}_{50}$ dari ekstrak metanol bunga brokoli sebesar 123,698 ppm dan vitamin C murni 3 ppm pada metode DPPH sehingga dapat disimpulkan vitamin $\mathrm{C}$ murni memiliki aktivitas peredaman radikal bebas yang lebih kuat dibandingkan dengan ekstrak metanol bunga brokoli yang memiliki aktivitas antioksidan sedang. bunga brokoli memberikan aktivitas peredaman radikal bebas yang lebih kecil karena penelitian ini masih berupa ekstrak kasarnya bukan senyawa murni, sehingga masih terdapat kemungkinan senyawa murni yang dikandung memiliki aktivitas peredaman radikal bebas lebih kuat dibandingkan dengan ekstrak kasarnya.

Faktor lain yang juga mempengaruhi yaitu kandungan senyawa antioksidan yang sedikit dalam ekstrak akibat waktu maserasi yang singkat yaitu 1 hari jika dibandingkan dengan teori dimana maserasi biasanya dilakukan selama 3-5 hari (Ansel, 1989) sehingga senyawa yang berkhasiat sebagai antioksidan tidak ditarik dengan sempurna.

Pada metode ABTS, pengukuran aktivitas antioksidan ekstrak metanol bunga brokoli (Brassica oleracea L. var. Italica) termasuk golongan antioksidan sangat kuat dengan nilai $\mathrm{IC}_{50}$ sebesar 32,1292 ppm dan vitamin C murni sebagai pembanding dengan nilai $\mathrm{IC}_{50}$ sebesar $6 \mathrm{ppm}$.

Tingkat kekuatan antioksidan dikatakan sangat kuat apabila memiliki nilai $\mathrm{IC}_{50}$ lebih kecil dari 50 ppm (Edhisambada, 2011). Dari hasil penelitian, maka dapat disimpulkan bahwa metode ABTS lebih baik dibandingkan dengan metode DPPH. Selain hasil yang diperoleh, pengerjaan dari metode ABTSpun lebih cepat dibandingkan metode DPPH.

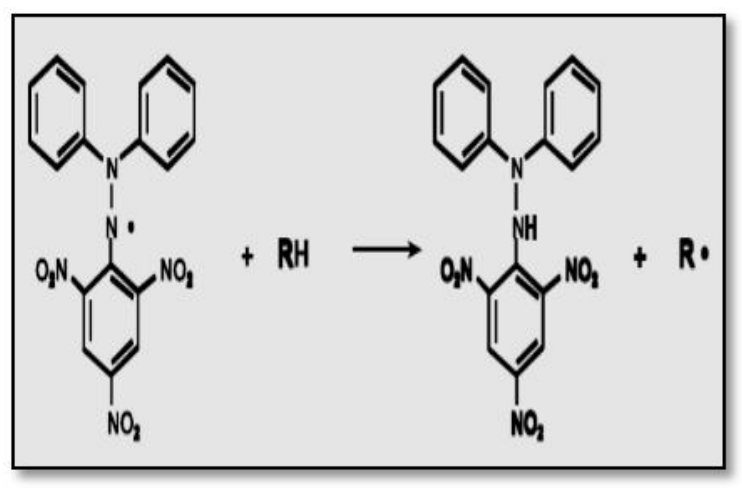

Gambar 1. Reaksi DPPH dengan antioksidan 


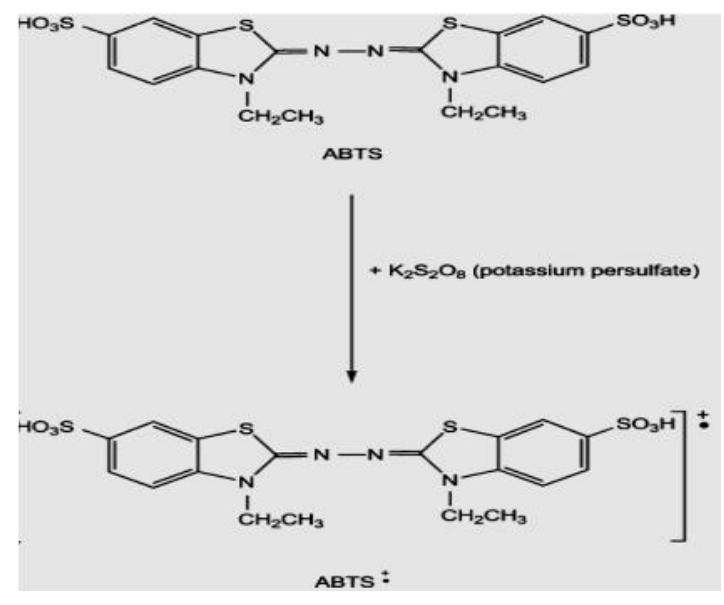

Gambar 2. Reaksi pembentukan ABTS radikal dari ABTS dengan kalium persulfat

\section{KESIMPULAN}

Dari hasil penelitian yang dilakukan dapat disimpulkan bahwa:

1. Pengujian aktivitas antioksidan dengan metode DPPH menunjukkan aktivitas antioksidan yang sedang dengan nilai $\mathrm{IC}_{50}$ sebesar $123,698 \mathrm{ppm}$ dan bila dibandingkan dengan vitamin $\mathrm{C}$ murni yang memiliki nilai $\mathrm{IC}_{50}$ sebesar $3 \mathrm{ppm}$ maka sampel mempunyai aktivitas antioksidan yang lebih rendah

2. Pengujian aktivitas antioksidan dengan metode ABTS menunjukkan aktivitas antioksidan yang sangat kuat dengan nilai $\mathrm{IC}_{50}$ sebesar 32,1292 ppm dan bila dibandingkan densgan vitamin $\mathrm{C}$ murni yang memiliki nilai $\mathrm{IC}_{50}$ sebesar $6 \mathrm{ppm}$ maka sampel mempunyai aktivitas antioksidan yang lebih rendah.

\section{DAFTAR PUSTAKA}

Ansel, H. Pengantar Bentuk Sediaan Farmasi Edisi IV. Jakarta: Universitas Indonesia Press. 1989

Edhisambada. 2011. Metode Uji Aktivitas Antioksidan Radikal 1,1-Difenil-2Pikrilhidrazil (DPPH). http://edhisambada.wordpress.com. $\quad(10$ september 2013).

Miksusanti et,al. Aktivitas Antioksidan dan Sifat Kestabilan Warna Campuran Ekstrak Etil Esetat Kulit Buah Manggis (Garcinia mangostana L.) dan Kayu Secang (Caesalpinia sappan L.). Sumatera Selatan: Jurusan Kimia Universitas Sriwijaya, 2012. Vol 15 Nomor 2 C, p 1-2
Moon JK, Shibamoto T. Antioxidant assays for plant and food components. Journal of Agricultural and Food Chemistry. 2009. Nomor 57, p 1655-1666.

Jusuf, Nelva Karmila. Pengaruh Ekstrak Bunga Brokoli (Brassica oleraceae L. var Italica Plenk) Terhadap Penghambatan Penuaan Kulit Dini (Photoaging): Kajian pada Ekspresi Matriks Metalloproteinase-1 dan Prokolagen Tipe 1 Secara in vitro pada Fibroblas Manusia. Medan: Fakultas Kedokteran Sumatera Utara, 2012. p 6

Widyastuti, N. Pengukuran Aktivitas Antioksidan dengan Metode CUPRAC, DPPH dan FRAP serta Korelasinya dengan Fenol dan Flavonoid pada Enam Tanaman. Departemen Kimia Fakultas Matematika dan Ilmu Pengetahuan Alam Institut Pertanian Bogor. 2010

Winarsi, Hery. Antioksidan Alami dan Radikal Bebas. Yogyakarta: Penerbit Kanisius, 2007. p 15

Yuliani, Fitri. Isolasi Senyawa Lutein Dari Ekstrak Bunga Brokoli Sebagai Antioksidan. Bogor: Fakultas MIPA Institut Pertanian Bogor, 2012. p 9 